
World Ecology

\title{
Strategic planning for sustainable tourism development in Poland
}

Marek Nowacki, Joanna Kowalczyk-Anioł, Karolina Królikowska, Małgorzata Pstrocka-Rak \& Matylda Awedyk

To cite this article: Marek Nowacki, Joanna Kowalczyk-Anioł, Karolina Królikowska, Małgorzata Pstrocka-Rak \& Matylda Awedyk (2018): Strategic planning for sustainable tourism development in Poland, International Journal of Sustainable Development \& World Ecology, DOI: 10.1080/13504509.2018.1432513

To link to this article: https://doi.org/10.1080/13504509.2018.1432513

册Published online: 26 Jan 2018.

Submit your article to this journal $₫$

Џ Article views: 15

Q View related articles ¿

View Crossmark data ־ 


\title{
Strategic planning for sustainable tourism development in Poland
}

\author{
Marek Nowacki ${ }^{\mathrm{a}}$, Joanna Kowalczyk-Anioł ${ }^{\mathrm{b}}$, Karolina Królikowska ${ }^{\mathrm{c}}$, Małgorzata Pstrocka-Rak ${ }^{\mathrm{d}}$ \\ and Matylda Awedyk
}

aDepartment of Economics, WSB University, Poznań, Poland; ' Institute of Urban Geography and Tourism, University of Lodz, Lodz, Poland; Institute of Tourism, WSB University in Wroclaw, Wroclaw, Poland; ${ }^{d}$ Deparment of Tourism, University School of Physical Education in Wroclaw, Wroclaw, Poland; 'Department of Geoecology of Tourism and Recreation, Poznan University of Physical Education, Poznan, Poland

\begin{abstract}
The aim of this article is to evaluate selected tourism development strategies in Poland, in the context of strategic planning, stakeholders' participation, and sustainable development principles. A questionnaire evaluation of strategy (44 questions) was established and based on measurement scales developed and validated by other authors in earlier studies. The five authors of the study rated 37 tourism development strategies in 13 provinces, 11 cities, 5 counties, 6 municipalities, and 2 other areas. Analysis revealed that they implement paradigms of sustainable development of tourism to only a small extent. Definitely higher quality is documented for higher levels of administrative division. The highest rated domains of the tourism development strategy in the examined documents are Strategic Planning Indicators and Implementation, Monitoring, and Evaluation.
\end{abstract}

\section{ARTICLE HISTORY}

Received 6 November 2017 Accepted 21 January 2018

\section{KEYWORDS}

Sustainable development; strategic planning; tourism development; regional development

\section{Introduction}

Sustainable development is understood as a "process to meet the needs of the present generation, without jeopardizing the ability of future generations to meet their own needs. "([WCED] World Commission on Environment and Development 1987, p.41). In particular, sustainability issues are considered now in four dimensions: political, economic, socio-cultural, and ecological (Sharpley 2009; Ritchie and Crouch 2003). In territorial units, sustainable development is realized through strategic management, which is reflected in the development strategy (Niezgoda 2006, p. 221-222). In addition to the overall local or regional development strategy, sectoral strategies, including tourism development strategies, are also being developed. The development strategy for tourism in the region, as argued by Ritchie and Crouch (2003, p. 31), should be part of the overall socio-economic development planning process in the region for two reasons: first, it will be developed because it will have to respond to similar questions but in a broader context, and second, because its goals will not be achieved unless they are in harmony with the overall plan. The most important prerequisite for building a tourism development strategy in the region is to improve the quality of life of the local community, by increasing the number and/ or expenditure of tourists in the region, while maintaining the principles of sustainable development (Niezgoda 2006; Carter 2007; Gołembski 2009).
Sustainable tourism is now perceived mostly as the normative orientation that seeks to change behavior in order to achieve sustainable development goals; however, it is required to make trade-offs between these goals rather than seek the perfect balance between them. Sustainable tourism is also increasingly assumed as relevant for all forms of tourism, regardless of scale, including mass-tourism (Bramwell et al. 2017). Currently, the concept of sustainable tourism brings together social, cultural, economic, and political alongside environmental issues. Although sustainability has its origin in environmentalism at some point of discussion, the critique arose about the lack of balance in the concept of sustainability regarding its human actors and their needs (Butler 1999). According to some researchers, our main task is not to limit growth within the meaning of classical book of Meadows et al. (1972) but to manage growth in a way that is appropriate to the tourists, the destination environment, and the host population (Liu 2003). In recent years, some key issues in sustainable tourism framework have been reframed (Bramwell et al. 2017). For example, it is suggested that sustainable tourism research and policies are too concentrated on behaviors of individual actors instead of considering wider social relations and structures, social norms and institutional rules, social capital and governance regimes, as well as systems of production and consumption (Bramwell et al. 2017; Gössling et al. 2012; Hall 2013; Nunkoo 2017). Moreover, there is the 
growing interest in whole systems perspectives connecting human and natural systems. In this area, tourism studies are adopting ideas and concepts from general systems approach to social-ecological systems analysis, like resilience and vulnerability, as of yet widely present in research on climate change, ecosystem services, or water governance (e.g. Butler 2017; Cheer and Lew 2017). The conceptualization of sustainable tourism affects associated policies and actions when we apply theoretical constructs in practice.

The basic assumptions of sustainable tourism are formulated in international documents that are the final result of the deliberations of international bodies related to tourism and nature protection. The most important are:

- Agenda 21 for Travel and Tourism Industry (Agenda 21 for the Travel and Tourism Industry) developed in 1996 jointly by the World Travel and Tourism Council, the World Tourism Organization and the Earth Council. It was created on the basis of the Global Action Program - Agenda 21: Program of Action for Sustainable Development.), adopted during the Earth Summit in Rio de Janeiro in 1992 ([WTTC] World Travel \& Tourism Council, [UNWTO] World Tourism Organization, [EC] Earth Council 1996);

- Charter for Sustainable Tourism - formulated by participants of World Conference on Sustainable Tourism in 1995 (Global Development Research Center 2018);

- Global Sustainable Tourism Criteria - adopted in 2008 at the World Conservation Congress (Global Sustainable Tourism Council 2018).

According to the UNWTO (2017), the principles of sustainable development relate to the environmental, economic, and socio-cultural aspects of tourism development, and the right balance between these three dimensions should be maintained in order to guarantee their long-term sustainability. According to the above, sustainable tourism should (UNWTO 2017):

(1) optimally use environmental resources that are a key element in the development of tourism, maintain basic ecological processes, and contribute to the preservation of natural and biological diversity;

(2) respect the socio-cultural authenticity of reception area communities, save their material and living cultural heritage, traditional values, and contribute to intercultural understanding and tolerance;

(3) safeguard the vital and long-term operation of the economy, providing socio-economic benefits for all stakeholders, including stable employment, income, and social services for reception area communities and contribute to poverty reduction.

The sustainable development of tourism requires the conscious action of all interested parties, as well as strong political leadership, in order to ensure broad stakeholder involvement and to reach consensus among them. Achieving sustainable tourism is a continuous process and requires ongoing monitoring of the changes that it entails, the introduction of necessary preventive measures, and, where necessary, corrective action (UNWTO: definition of sustainable development of tourism 2017).

So far, there is little research to assess the degree of implementation of sustainable development in tourism development plans. As one of the first, Simpson (2001) has developed a questionnaire for evaluating tourism development plans for the implementation of sustainable development. The questionnaire consisted of 51 claims he grouped in five domains: stakeholders' participation, vision and values, environmental analysis, objectives and assumptions, implementation and evaluation. With this questionnaire, he assessed 19 regional tourism development plans in New Zealand. In other studies, Ruhanen (2004), using the tool developed by Simpson, evaluated 30 tourism development plans in Queensland's tourism destinations (Australia). The purpose of the study was to verify whether the assumptions of sustainable development (strategic planning and participation of stakeholders) are present in the planning of tourism development (she concluded that they are not).

The aim of this article is to evaluate selected tourism development strategies in Poland, in the context of the principles of strategic planning, stakeholders' participation, and the principles of sustainable tourism development.

\section{Methodology}

Construction of the research tool began with a review of the literature on the evaluation of strategic documents in the tourism sector. The initial questionnaire evaluation of the strategy was based on the measurement scales developed and validated by Simpson (2001) and Ruhanen (2004). On this basis, a questionnaire with 51 questions on various elements of the strategy was grouped into five parts: (1) strategic planning indicators, (2) environmental analysis, (3) stakeholders' involvement and their impact on the strategic planning process, (4) vision and values, and (5) implementation, monitoring, and evaluation. The questionnaire was then subjected to an expert assessment. Seven renowned experts with experience in creating and/or evaluating tourism development strategies in the region assessed each questionnaire question with a three-tier 
scale (from inadequate to appropriate). There also were given the opportunity for experts to propose their own suggestions for wording of questions as well as to formulate additional questions not included in the questionnaire. The question which received four inadequate assessments was removed from the questionnaire. In this way, 44 questions were left in the final questionnaire.

Then, using a questionnaire, six authors of the article evaluated 37 tourism development strategies in the regions: 13 provinces (updated and available to the public), 11 cities, and 13 local (5 counties, 6 municipalities, 2 other areas). Due to a limited number of strategic papers on the development of tourism in the regions, the authors have decided to classify (for a given spatial unit) the most recent available documents. Strategies were taken from Public Information Offices Newsletters and Bulletins. Only those documents that have been approved separately (not part of general strategies) have been evaluated. The selected group was supposed to be able to compare the quality of the strategies developed at various levels of the country's administrative division. Individual elements of the strategy were assessed using a four-step scale: 0 - not included in the strategy, 1 - tracer/short/ weak record, 2 - partial/average record, 3 - complete/ large/very good record (the question of the time horizon of the strategy was excluded from the qualitative assessment, where the number of years included in the strategy horizon were assumed). In order to investigate the reliability of the measurement scales, i.e. the consistency of the questions in each of the five parts of the questionnaire, a Cronbach coefficients were calculated. For four domains, the Cronbach a coefficient has exceeded the required level of 0.70 (Hair et al. 2007, p. 137), which means sufficient scale reliability. Only the factor 'stakeholders' involvement' a was 0.645. Analysis of the theorems of this part showed that after removing one of the claims (the strategy included the opinions of existing visitor segments), the $a$ coefficient has adopted the accepted value of 0.708 (this is probably due to a very low frequency of occurrences of this element in comparison with the other elements of this part of the questionnaire) (Table 1). Thus, in the final questionnaire, 42 assertions

Table 1. Cronbach a coefficient values for questionnaire scales.

\begin{tabular}{lcc}
\hline Strategy domain & $\begin{array}{c}\text { Number of } \\
\text { assertions }\end{array}$ & $\begin{array}{c}\text { Cronbach } a \\
\text { coefficient }\end{array}$ \\
\hline Strategic planning indicators & 11 & 0.716 \\
Environmental analysis & 14 & 0.858 \\
Stakeholder participation in the & 5 & 0.708 \\
$\quad$ planning Process & & \\
Vision and values & 6 & 0.870 \\
Implementation, monitoring and & 6 & 0.713 \\
$\quad$ evaluation & & \\
In total & 42 & 0.909 \\
\hline
\end{tabular}

Source: own research. were remained, and a Cronbach's coefficient for all 42 assertions was very high and amounted to 0.909 , which confirmed the high reliability of the tool developed.

In order to investigate the compatibility of the ratings made by the five authors, the rater agreement index was calculated (Burry-Stock et al. 1996). This index takes values between 0 and 1 , where values above 0.70 testify to the high compliance of the judges in the ratings given. The calculated index of correspondence ratings granted by the five authors of the article on the evaluation of 37 strategies was 0.752 , and was therefore considered sufficient.

Differences between strategies were verified with the nonparametric tests: Mann-Whitney $U$ test (for comparing two groups) and Kruskal-Wallis $\mathrm{H}$ test (for comparing multiple groups).

\section{Results}

The analysis of the values obtained by each domain of the strategy showed that the highest ratings were attributed to the Strategic Planning Indicators $(x=1.290$, in this respect very agreeable as $\delta=0.345)$ and Implementation, Monitoring and Evaluation ( $\bar{x}=1.206, \delta=0.544)$. The lowest authors rated the part of Vision and Values $(\bar{x}=0.781)$ - also with high agreement $(\delta=0.423$ ) (Table 2), which means that the authors of the least evaluated strategies were devoted to the analysis of values, sociodemographic and lifestyle characteristics, and attitudes of local communities in terms of tourism, and to a small extent incorporated these elements into the visions of tourism development.

\subsection{Strategic planning indicators}

The first analyzed indicator of strategic planning was the time horizon of the strategy. The analyzed strategies were created in 2003-2016, and their time horizon ranged from 0 (no time horizon) to 14 years. The most frequent planning horizon was 8 years (six stra-

Table 2. Distribution of values obtained by individual domain of strategies.

\begin{tabular}{lcccc}
\hline $\begin{array}{c}\text { Strategy domain } \\
\text { Strategic } \\
\text { planning } \\
\text { indicators }\end{array}$ & Average $(\bar{x})$ & Minimum & Maximum & $\begin{array}{c}\text { Standard } \\
\text { deviation }(\delta)\end{array}$ \\
$\begin{array}{c}\text { Environmental } \\
\text { analysis }\end{array}$ & 1.290 & 0.600 & 1.872 & 0.345 \\
$\begin{array}{c}\text { Stakeholder } \\
\text { participation in } \\
\text { the planning } \\
\text { process }\end{array}$ & 1.137 & 0.280 & 2.320 & 0.586 \\
$\begin{array}{l}\text { Vision and values } \\
\text { Implementation, } \\
\text { monitoring } \\
\text { and evaluation }\end{array}$ & 0.781 & 0.166 & 1.733 & \\
\hline
\end{tabular}

Source: own research. 
tegies), 10, 11, and 13 years (five strategies), and 6, 7 years (four strategies). It can be stated that the planning horizon is increasing, along with the year of strategy development: the newer the strategy, the longer the horizon. Of the remaining 11 elements of this section, top rated was the implementation of the specific objectives of the strategy for general purposes of strategies $(2.31),{ }^{1}$ the formulation of specific targets based on supply (2.05), and the definition of objectives related to the direction and scale of tourism development in the region (2.10). Unfortunately, only eight of the documents formulated alternative scenarios for the strategy (0.30), with only four scoring each of these scenarios (0.18).

\subsection{Environmental analysis}

In each of the strategies evaluated, the integration of the document with other strategies (2.43) and the characteristics of the geographic environment (2.09) were indicated. Normally, the strategies enumerate protected areas, but do not characterize habitats and endangered species. Most of the documents describe the capacity of the tourism infrastructure, although they do not estimate the area's absorption (1.74). Often were pointed out the primary places of concentration of tourism in the region (1.47). Unfortunately, in any strategy, neither the porosity nor the sensitivity of the natural environment is evaluated. Only 13 documents have identified the ownership structure of the land, and in only 12, the business capabilities of local tourism operators. The authors of these documents did not attach much importance to the negative effects of tourism development: e.g. crowding in places of concentrated tourist traffic (e.g. on the Great Masurian Lakes Trail), pathological phenomena caused by tourist traffic (e.g. in the Old Town in (racow), environmental pollution, or landscape degradation. Only occasionally were there pointed out actual or potential conflicts between tourism function and other forms of space use (e.g. military, environment, agriculture). The market segmentation of visitors was usually based on the area's tourism potential or the hypotheses (propositions) of the experts developing the strategy.

\subsection{Stakeholder participation in the planning process}

The involvement of local or regional stakeholders in the planning process was usually limited to representatives of local or regional tourism operators (1.53). The documents often performed an analysis of the development of tourism stakeholders in the region (1.27). The residents themselves were the least likely to participate in the planning of tourism development in the region: in just 11 cases, of 37 evaluated, were consultations conducted among the residents of the tourism reception area. Most of the consultations were conducted with local authorities at various levels or representatives of the local tourism market. In none of the documents was there information on the strategy used in consulting with representatives of the tourism segments and other visitors to the region.

\subsection{Vision and values}

This is the least evaluated part of the strategy by the authors. An analysis of the vision formulated in their strategies indicates that many of them identified current issues of relevance to residents (1.18), and also identified values important to the community (0.96). However, almost no strategy outlines the overall quality and characteristics of the lifestyle of the area residents, nor the attitudes towards tourism development.

\subsection{Implementation, monitoring, and evaluation}

A set of indicators to monitor the implementation of the strategy was well developed in the vast majority of documents (1.74) and clearly defined the responsibility of the actors for implementing key tasks (1.54). Strategies, fairly well, formulated a mechanism for monitoring and evaluation (1.51). Only one document contains a forecast of the possible impacts on the environment.

\subsection{The quality of the strategy and the size of the region, the date of development, and the time horizon}

At the last stage of the analysis, the strategies assessed differences in terms of the area they were involved in, the date of development, and the time horizon of the strategy (Table 3 ). Comparing provincial strategies $(n=13)$ with urban $(n=11)$ and the others $(n=13)$, there was a much higher quality of the former in only one domain: environmental analysis $(H=9.26, p=0.009)$. There were no significant differences between the older and newer strategies and the time horizon of the document.

\section{Conclusions}

The analysis allowed for the following conclusions:

(1) The overall quality of the documents reviewed varies. Definitely higher quality is documented for higher levels of administrative division, which is probably due to lower financial and technical constraints. Perhaps, as suggested by Niezgoda (2006, p. 228), the creation of separate strategy papers for different areas at the lower levels is an obstacle in achieving developmental goals. 
Table 3. Quality of the strategy versus area size, date of development, and time horizon.

\begin{tabular}{|c|c|c|c|c|c|c|}
\hline Strategy domain & $\begin{array}{l}\text { Strategic planning } \\
\text { indicators }\end{array}$ & $\begin{array}{l}\text { Environmental } \\
\text { analysis }\end{array}$ & $\begin{array}{l}\text { Stakeholder participation in the } \\
\text { planning process }\end{array}$ & $\begin{array}{l}\text { Vision and } \\
\text { values }\end{array}$ & $\begin{array}{l}\text { Implementation, monitoring } \\
\text { and evaluation }\end{array}$ & $n$ \\
\hline \multicolumn{7}{|l|}{ Strategy area } \\
\hline Provincial & 1.439 & 1.407 & 1.326 & 0.846 & 1.244 & 13 \\
\hline Urban & 1.183 & 0.840 & 1.011 & 0.594 & 1.239 & 11 \\
\hline Others & 1.231 & 1.193 & 1.055 & 0.877 & 1.141 & 13 \\
\hline $\begin{array}{l}\text { Kruskal-Wallis } \mathrm{H} \\
\text { test }\end{array}$ & $3.44(0.18)$ & $9.26(0.009)$ & $1.98(0.37)$ & $4.34(0.11)$ & $0.33(0.5)$ & \\
\hline \multicolumn{7}{|l|}{ Date of execution } \\
\hline Until 2010 & 1.280 & 1.177 & 1.110 & 0.750 & 1.085 & 20 \\
\hline Since 2011 & 1.302 & 1.147 & 1.169 & 0.820 & 1.349 & 17 \\
\hline $\begin{array}{l}\text { Mann-Whitney U } \\
\text { test }\end{array}$ & $-0.38(0.70)$ & $0.24(0.80)$ & $-0.18(0.85)$ & $\begin{array}{l}-0.41 \\
(0.68)\end{array}$ & $-1.49(0.14)$ & \\
\hline \multicolumn{7}{|l|}{ Time horizon } \\
\hline $0-8$ years & 1.237 & 1.125 & 1.061 & 0.696 & 1.137 & 19 \\
\hline 9 and more years & 1.346 & 1.203 & 1.218 & 0.872 & 1.280 & 18 \\
\hline $\begin{array}{l}\text { Mann-Whitney U } \\
\text { test }\end{array}$ & $0.98(0.32)$ & $0.60(0.54)$ & $1.03(0.30)$ & $1.29(0.19)$ & $0.82(0.41)$ & \\
\hline
\end{tabular}

Source: own research.

(2) In light of the method used, the highest rated domains of the tourism development strategy in the 37 Polish cities and areas are Strategic Planning Indicators ( $\bar{x}=1.290)$, Implementation, Monitoring, and Evaluation $(\bar{x}=1.206)$, and least Visions and Values $(\bar{x}=0.781)$.

(3) Analyzed strategies moderately implement sustainable tourism development paradigms. Despite the often-declared expert-participatory type of strategy, when created, only a few were consulted for their content with the residents of reception areas and almost none analyzed the nature of the local community, lifestyle features, and attitudes towards tourism down to the neighborhood level. There was also no estimated absorption in tourism concentration areas (p. 1 and 2 of UNWTO Recommendations, UNWTO: definition of sustainable development of tourism 2017). The assessed strategies do not take into account potential negative effects of tourism development on local communities. Little attention has been paid to the impact of tourism on the natural environment. The analysis of natural resources, in diagnostic parts, was performed in terms of tourism value rather than the sensitivity of the area to anthropopression. Rare was the inclusion of strategic environmental impact assessment documentation.

(4) Long-term planning, i.e. taking into account the time horizon of more than 15 years, is still rarely used in the development strategies employed in Poland. This also applies to the analysis of alternative scenarios development. Lack of long-term vision development and failure to take into account events that may adversely affect the attainment of goals may consequently prevent the implementation of strategies and the continuation of the future issues.

(5) The analyzed documents also differ significantly in terms of their volume, to a lesser extent construction, graphic form, sources used, and nature of the data. Only some meet the requirements of modern strategies. Several have a scientific context, another extensive marketing narrative. Only part of the strategy (to a small extent) refers to the study of tourism demand.

(6) Lack of significant differences between older and newer strategies indicates a lack of improvement in the quality of emerging strategies in Poland. Although the analyzed strategies were created in different periods and under different conditions, their quality, and especially the elements of sustainable development, has not improved significantly in recent years.

Obviously, there are real problems of implementing the principles of sustainable tourism in current economic environment in Poland. In this respect, the declaration expresses in various policies must at least be put into practice.

There are two groups of issues that we must consider (Niezgoda 2004): (1) general developmental issues relating to systemic solutions and to the state of the country and society; (2) specific issues concerning tourism development based on the principles of sustainable tourism. Among the general considerations, the first problem relates to the planning process and the issue of government policy cohesion. The policy of sustainable development, as applied to spatial planning and tourism, can and should be a synthesis of policies of various government departments. For many people in Poland, the very idea of planning brings the memories of the long-gone and negatively perceived political system of central planning; hence, the role of correctly constructed development plans and strategies might not be properly appreciated. And yet sustainable development relies on a longterm perspective, hence it requires a strategy looking ahead 10 to 15 years. Frequent staff rotation at 
ministerial positions and alternation of government coalitions are responsible for the lack of cohesion in strategic policies. The problem also extends to lower levels of state administration, including local governments.

To achieve cohesion in the guidelines and decisions at different levels of administration and management, the issue of sustainable development must be clearly understood by all players, and this requires proper communication channels.

\section{Note}

1. In parentheses, is given the average rate to an item among all 37 strategies.

\section{Acknowledgments}

The authors would like to thank the six experts who made it possible to develop an in-depth research tool.

\section{Disclosure statement}

No potential conflict of interest was reported by the authors.

\section{References}

Bramwell B, Higham J, Lane B, Miller G. 2017. Twenty-five years of sustainable tourism and the Journal of Sustainable Tourism: looking back and moving forward. J Sustainable Tourism. 25(1):1-9.

Burry-Stock JA, Shaw DG, Laurie C, Chissom BS. 1996. Rater agreement indexes for performance assessment. Educ Psychol Meas. 56(2):251-262.

Butler RW. 1999. Sustainable tourism: a state-of-the-art review. Tourism Geographies. 1(1):7-25.

Butler RW, editor. 2017. Tourism and resilience. Wallingford: CABI.

Carter R, editor. 2007. A practical guide to tourism destination management. Madrid: United Nations World Tourism Organization.

Cheer JM, Lew AA, editors. 2017. Tourism, resilience and sustainability: adapting to social, political and economic change. Abingdon: Routledge.

Global Development Research Center. 2018. Charter for sustainable tourism. [accessed 2018 Jan 6]. http://www.gdrc. org/uem/eco-tour/charter.html.
Global Sustainable Tourism Council. 2018. Global sustainable tourism criteria. [accessed 2018 Jan 6]. http://www. gstcouncil.org/gstc-criteria.

Gołembski G. 2009. Zintegrowane zarządzanie jakością w turystyce [Integrated quality management in tourism]. In: Gołembski G, editor. Kompendium wiedzy o turystyce [Compendium on tourism]. Warszawa: Wydawnictwo Naukowe PWN; p. 323-402.

Gössling S, Hall CM, Ekström F, Engeset AB, Aall C. 2012. Transition management: a tool for implementing sustainable tourism scenarios? J Sustainable Tourism. 20(6):899916.

Hair JF, Black WC, Babin B, Anderson RL, Tatham RL. 2007. Multivariate data analysis. New Jersey (NJ): Prentice Hall.

Hall CM. 2013. Framing behavioural approaches to understanding and governing sustainable tourism consumption: beyond neoliberalism, "nudging" and "green growth"? J Sustainable Tourism. 21(7):1091-1109.

Liu Z. 2003. Sustainable tourism development: a critique. J Sustainable Tourism. 11(6):459-475.

Meadows DH, Meadows DL, Randers J, Behrens WW. 1972. The limits to growth. New York: Universe.

Niezgoda A. 2004. Problems of implementing sustainable tourism in Poland. Poznań Univ Econ Rev. 4(1):30-42.

Niezgoda A. 2006. Obszar recepcji turystycznej w warunkach rozwoju zrównoważonego [Area of tourist reception in sustainable development conditions]. Poznań: Wydawnictwo Akademii Ekonomicznej w Poznaniu.

Nunkoo R. 2017. Governance and sustainable tourism: what is the role of trust, power and social capital? J Destination Marketing Manag. 6(4):277-285.

Ritchie JRB, Crouch GI. 2003. The competitive destination. a sustainable tourism perspective. Wallingford (UK): CABI Publishing.

Ruhanen L. 2004. Strategic planning for local tourism destinations: an analysis of tourism plans. Tour Hospit Plann Dev. 1(3):239-253.

Sharpley R. 2009. Tourism development and the environment: beyond sustainability? London: Earthscan.

Simpson K. 2001. Strategic planning and community involvement as contributors to sustainable tourism development. Curr Issues Tour. 4(1):3-41.

UNWTO: definition of sustainable development of tourism. 2017. United Nations World Tourism Organization. [accessed 2017 Oct 20]. http://sdt.un-wto.org/content/ about-us-5.

[WCED] World Commission on Environment and Development. 1987. Our common future. Oxford (UK): Oxford University Press.

[WTTC] World Travel \& Tourism Council, [UNWTO] World Tourism Organization, [EC] Earth Council. 1996. Agenda 21 for the travel \& tourism industry: towards environmentally sustainable development. Madrid: WTTC. 